AperTO - Archivio Istituzionale Open Access dell'Università di Torino

\title{
An overview of organic aquaculture in Italy
}

\section{This is the author's manuscript}

Original Citation:

Availability:

This version is available http://hdl.handle.net/2318/1704676

since 2019-06-20T14:27:51Z

Published version:

DOI:10.1016/j.aquaculture.2019.05.024

Terms of use:

Open Access

Anyone can freely access the full text of works made available as "Open Access". Works made available under a Creative Commons license can be used according to the terms and conditions of said license. Use of all other works requires consent of the right holder (author or publisher) if not exempted from copyright protection by the applicable law. 


\section{Manuscript Details}

\section{Manuscript number}

Title

Article type
AQUA_2017_1118_R2

An overview of organic aquaculture in Italy

Review Article

\section{Abstract}

The total Italian organic aquaculture production in 2015 was of $2347 \mathrm{t}$, and it accounted for almost $1.1 \%$ of the total Italian aquaculture. This situation is comparable with that of other western countries, where organic production accounts for about $1.5-2 \%$ of the total aquaculture production. Between 2013 and 2014, the number of organic fish farms in Italy more than doubled, that is, from 17 to 41 farms. Most of these organic fish farms are located along the Adriatic coast and in North East Italy (Veneto region), and the main farmed species in that period was blue mussel, followed by gilthead sea bream and rainbow trout. Organic aquaculture is generally considered a promising and growing sub-sector of aquaculture in Italy and in other European countries, and a number of supporting research initiatives have recently been implemented by the Italian Ministry of Agriculture and Forestry. However, despite these efforts, a clear fact has emerged: only a small percentage of Italian fish farmers demonstrated any interest in producing organically until 2013. The demand for organic aquaculture products in Italy is increasing, particularly among people that are regular organic food consumers. However, there are a number of critical aspects that still need to be addressed: the difficulty of introducing organic aquaculture products into large-scale retail operations, the high prices of the key fish feed ingredients, the difficulties in adapting Directive (EC) 710/2009 to aquaculture and the application of long-term marketing strategies. This paper tries to provide a realistic perspective of organic aquaculture, and thus includes not only the proximate causes (i.e. technical and regulatory aspects) of the current production, but also the remote historical, geographical, political and arithmetical reasons.

Keywords

Taxonomy

Manuscript category

Corresponding Author

Corresponding Author's Institution

Order of Authors

Suggested reviewers

Opposed reviewers organic aquaculture; consumer information; Italian aquaculture; aquaculture products; organic fish farm

Aquaculture, Aquaculture Sustainability

Sustainability and Society

Benedetto Sicuro

University of Turin

Benedetto Sicuro

Leo Nankervis, Mattew Slater, Costas Perdikaris, Patrick Williot, Giuseppe Lembo, Umberto Luzzana, Ioannis Paschos

Marco Saroglia 


\section{Submission Files Included in this PDF}

\section{File Name [File Type]}

Aquaculture BIO Italia - Answer to reviewers - April 19th 2019.docx [Response to Reviewers]

Sicuro 2019 - Org aquac - Highlights.docx [Highlights]

Sicuro 2019 - Organic aquaculture in Italy - REV April 8th 2019.docx [Manuscript File]

Sicuro 2019 - Organic aquaculture in Italy - Figure 1 - updated.docx [Figure]

Sicuro 2017 - Organic aquaculture in Italy - Figure 2.docx [Figure]

Sicuro 2019 - Org aquac- Fig 3.docx [Figure]

Sicuro 2019 - Org aquac - Tab 1.docx [Table]

Sicuro 2017 - Organic aquaculture in Italy - Aquaculture - Figure captions.docx [Table]

Sicuro 2019 - Org aquac - TITLE PAGE.docx [Author Statement]

Sicuro 2019 - Org aquac - 3rd letter to editor - April 19th 2019.docx [Author Statement]

To view all the submission files, including those not included in the PDF, click on the manuscript title on your EVISE Homepage, then click 'Download zip file'.

\section{Research Data Related to this Submission}

There are no linked research data sets for this submission. The following reason is given:

This manuscript is a review and I did not use any personal research data. I only analyzed aquaculture production data from different countries 


\section{Comments from the editors and reviewers:}

-Reviewer 1

\section{-Reviewer 2}

- The key information on Italy is some four years out of date - surely, much has changed since then.

I question some of the assertions in the paper, not least that the UK was the first organic fish producer in 2009 (1. 68). Aarset, Tveteras and Norwegian and UK colleagues had been researching and producing papers for a decade on the subject - see Aarset, B. et al. (2004). The European consumers' understanding and perceptions of the 'organic' food regime. The case of aquaculture. British Food Journal, 106, 93-105. It is also inconsistent with the statement you make in I. 263, where you state that 'Italian organic aquaculture is more than 20 years old ..'; this surely then predates 2009 by a decade.

Also, I dispute the fact that $100 \%$ of Irish farmed salmon and trout is organically produced, despite the BIM report.

English and grammar still require an overhaul e.g.

1. 50. '.. it is useful to consider Italy in an ..'.

1. 78. '.. in Europe is Ireland, which is ..'. 


\section{Dear Reviewer 2,}

thank you for your comments (in red) on my manuscript, here my answers to your questions.

The key information on Italy is some four years out of date - surely, much has changed since then.

I already updated references on Italian aquaculture in the last version of the manuscript (Di Marco et al., 2017), however, following your suggestions, in order to give to the reader a most possible updated description of Italian organic aquaculture, I searched new references, reports and articles eventually published in the last months, particularly in Italian. I did not find more recent data on production that are still referred to those of 2015, but I found new data on number of the farms, that confirm previous ones. The number of organic farm is still of 41 (see attached table)

I introduced following sentence in the manuscript:

"Recent data on organic fish farms (SINAB 2014; SINAB 2015) indicated an unexpected increase to 41 farms in 2014 with a successive stationary phase until 2017 (SINAB, 2018), thus showing an increase of more than 140\%."

I integrated these results in the manuscript and I updated Fig.2

The most relevant documents I found are:

-a project on organic aquaculture product consumers BIOBREED (2016)

(http://www.biobreed.it/BioBreed/HOME.html) carried out by Italian Council for Agricultural Research and Economics which become to the Italian Ministry of Research and University (MIUR)

- an Italian report of SINAB 2018 (http://www.openfields.it/sito/wp-content/uploads/2018/09/Bio-in-cifre-2018-_Anticipazioni.pdf) where I found updated information about Italian organic aquaculture farms (see table 9). This document is particularly interesting for organic aquaculture in Italy, in fact I already consulted previous issues of 2015 and 2014 (SINAB (2014). BIO in cifre 2014 1-81 Available at

http://www.sinab.it/sites/default/files/share/OK!!.pdf (In Italian); SINAB (2015) BIO in cifre 2015 1-94 Available at http://www.sinab.it/sites/default/files/share/OK!!.pdf (In Italian)

Sentence introduced in the manuscript:

positive aspect recently resulted by the project BIOBREED (http://www.biobreed.it/BioBreed/HOME.html) is the positive consumer's perception of organic aquaculture products as reaction to a general negative sentiment of conventional aquaculture products. Italian consumers believe that pharmaceutical treatments are strongly reduced in organic aquaculture (Pulcini \& Capoccioni 2018)..

Updated references

Pulcini D, Capoccioni F (2018). Il consumo di pesce allevato e biologico in Italia (in Italian). Edizioni Bet Multimedia pp 66. Available on line at

http://www.biobreed.it/BioBreed/HOME_files/Il\%20consumo\%20di\%20pesce\%20allevato\%20e\%20Biologico\%20in \%20italia.pdf

SINAB (2018) BIO in cifre - Anticipazioni 2018 1-94 Available online at http://www.openfields.it/sito/wpcontent/uploads/2018/09/Bio-in-cifre-2018-_-Anticipazioni.pdf (In Italian) pp 28 


\section{Tabella 9}

Aziende di acquacoltura biologica, anni 2016 e 2017

\begin{tabular}{|l|l|l|}
\hline & 2016 & 2017 \\
\hline TOTALE NAZIONALE & 40 & 40 \\
\hline VENETO & 15 & 15 \\
\hline EMILIA ROMAGNA & 15 & 11 \\
\hline PUGLIA & 3 & 2 \\
\hline FRIULI VENEZIA GIULIA & 1 & 2 \\
\hline LOMBARDIA & 1 & 2 \\
\hline SARDEGNA & 1 & 1 \\
\hline CALABRIA & 1 & 1 \\
\hline TRENTINO ALTO ADIGE & 1 & 1 \\
\hline UMBRIA & 1 & 1 \\
\hline CAMPANIA & 0 & 1 \\
\hline LAZIO & 0 & 1 \\
\hline MARCHE & 0 & 1 \\
\hline PIEMONTE & 1 & 0 \\
\hline
\end{tabular}

(Fonte SIB)

I question some of the assertions in the paper, not least that the UK was the first organic fish producer in 2009 (I. 68). Aarset, Tveteras and Norwegian and UK colleagues had been researching and producing papers for a decade on the subject - see Aarset, B. et al. (2004).

I corrected the paragraph and I introduced following sentence in the manuscript:

First European organic farms of salmon were accredited according to an IFOAM standard in 1999 (Aarset et al. 2004). In the following period, the United Kingdom was one of the leading country and in 2009

The European consumers' understanding and perceptions of the 'organic' food regime. The case of aquaculture. British Food Journal, 106, 93-105. It is also inconsistent with the statement you make in I. 263, where you state that 'Italian organic aquaculture is more than 20 years old ..'; this surely then predates 2009 by a decade

I don't understand completely the meaning of this comment, however, considering that we are in 2019 and fish organic production started in 2000 (see line 191 ... "Organic aquaculture production in Italy started in 2000 - 2001, with a few trout farms that were certified by independent certification bodies (AAVV, 2001) ..." it is about 20 years ago, so I cannot find anything wrong in that sentence. 
English and grammar still require an overhaul e.g.

1. 50. '.. it is useful to consider Italy in an ..'

1. 78. '.. in Europe is Ireland, which is ..'.

I sent again the manuscript for a second English revision, to the lecturer that I cited in the acknowledgment. I reintroduced all the English corrections she suggested me

Also, I dispute the fact that $100 \%$ of Irish farmed salmon and trout is organically produced, despite the BIM report.

I have just reported in the manuscript what is indicated in that report (BIM report), I did not find different information about organic aquaculture in Ireland.

Best regards,

Benedetto Sicuro 
2 Benedetto Sicuro ${ }^{1 *}$

$4 \quad$ Highlights of the manuscript

6 Organic aquaculture in Italy is considered a promising sector however it never reaches

7 expected previsions and shows a stationary low level of production $(1.1 \%$ of total

8 aquaculture production in 2015).

9 Blue mussel, gilthead sea bream and rainbow trout are the most important organically

10 farmed species in Italy, and most of the organic fish farms are located along the Adriatic

11 coast and in North East Italy.

12 The high costs of certification and fish feeds, the bureaucracy, the higher prices and the

13 lack of appropriate marketing strategies are the main practical obstacles for Italian 14 organic aquaculture. 


\section{An overview of organic aquaculture in Italy}

2 Abstract

3 The total organic aquaculture production in Italy in 2015 was of $2347 \mathrm{t}$, and it accounted

4 for almost $1.1 \%$ of the total aquaculture production. This situation is comparable with

5 that of other western countries, where organic production accounts for about $1.5-2 \%$ of

6 the total aquaculture production. Between 2013 and 2018, the number of organic fish

7 farms in Italy has more than doubled, that is, from 17 to 41 farms. Most of these organic

8 fish farms are located along the Adriatic coast and in North East Italy (Veneto region),

9 and the main farmed species in that period was blue mussel, followed by gilthead sea

10 bream and rainbow trout. Organic aquaculture is generally considered a promising and

11 growing sub-sector of aquaculture in Italy and in other European countries, and a number

12 of research initiatives have recently been implemented by the Italian Ministry of

13 Agriculture and Forestry. However, despite these efforts, a clear fact has emerged: only a

14 small percentage of Italian fish farmers demonstrated any interest in producing

15 organically until 2017. The demand for organic aquaculture products in Italy is

16 increasing, particularly among those people who regularly consume organic food.

17 However, there are a number of critical aspects that still need to be addressed: the

18 difficulty of introducing organic aquaculture products into large-scale retail operations,

19 the high prices of the key fish feed ingredients, the difficulties in adapting Directive (EC)

$20710 / 2009$ to aquaculture and the application of long-term marketing strategies. This paper

21 tries to provide a realistic perspective of organic aquaculture, and thus includes not only

22 the proximate causes (i.e. technical and regulatory aspects) of the current production, but

23 also the remote historical, geographical, political and arithmetical reasons. 
Kedywords: certified productions, European aquaculture, Italian aquaculture, organic 25 aquaculture, quality of products, rainbow trout,

\section{Introduction}

28 Organic aquaculture answers an urgent and common demand of consumers for better 29 quality seafood and a sustainable use of marine resources (Subasinghe et al. 2009;

30 Turchini et al. 2009; Tusche et al. 2011). For this reason, in these last 20 years, in Italy

31 and in Europe, consumer awareness about organic foods and organic fish production has

32 promoted the diffusion of various types of seafood eco-endorsements, such as eco-

33 labeling and certification (EU, 2014; Mente et al. 2011; Mente et al. 2012). The main

34 aspect that makes organic aquaculture different from conventional aquaculture is the fish

35 nutrition, which directly addresses consumer needs, food safety and environmental

36 concerns (Ballester-Moltó et al. 2017; Komas et al. 2014; Mente et al. 2011; Mente et al.

37 2012). A crucial issue is the reduction of fishmeal and fish oils in fish feeds with two

38 main objectives: the use of: (a) sustainable sources of fish meal and (b) alternative

39 vegetal feedstuffs (Menghe et al. 2006; Lund et al. 2011). In some cases, the limitations

40 imposed in the use of fish feed ingredients can cause an even higher environmental

41 impact than conventional aquaculture (Ballester-Moltó et al. 2017).

42 From its beginning, organic aquaculture (like almost any other organic production sector)

43 has often been depicted as having positive possibilities and expected growth, that is, of up

44 to $40 \%$ (AA. VV. 2001; Mansfield, 2007; Prein et al. 2012; Nizza 2012; Di Marco et al.

45 2017), but it has rarely passed 1 or $2 \%$ of the total aquaculture production. 
46 But is organic aquaculture in Italy really so promising and increasing, as has repeatedly

47 been stated ? What is the realistic perspective of organic aquaculture in Italy and in other

48 developed countries? Are the difficulties in the application of national rules the only

49 reasons that can explain this low production?

50 In order to try to answer to these questions, it is useful to include Italy in an international

51 and European context, and to briefly consider the historical, geographical, political and

52 social reasons that can explain this situation. In other words, to understand the real

53 perspectives of organic aquaculture in Italy, or elsewhere, it is important to include the

54 proximate and remote causes of the current status of organic aquaculture in the

55 discussion. The analysis of the Italian status of organic aquaculture may serve as a

56 comprehension and prevision model for other developed countries that, taken together,

57 represent the area that could undergo the greatest increase in organic aquaculture in the

58 future.

59 In light of the general upward trend of organic aquaculture products on the European

60 market, the aim of this paper has been to review the organic aquaculture situation in Italy,

61 and to consider the main driving forces that regulate this sector.

\section{The role of European aquaculture}

64 Blue mussel was the main organic production species in Europe in 2015 (Fig.1), followed

65 by Atlantic salmon, carp, sea bass and sea bream. In 2010 and 2011, salmon and trout

66 were the principal species organically farmed in Europe, while in Norway, organic

67 salmon was $1.3 \%$ of the total production in 2012 (Zubiaurre, 2013). 
68 First European organic farms of salmon were accredited according to an IFOAM standard 69 in 1999 (Aarset et al. 2004). In the following period, the United Kingdom was one of the

70 leading country and in 2009 the production of organic salmon was $4 \%$ of the total salmon

71 farmed in the country. Ireland was the largest European producing country of organic

72 salmon in 2012, with $9.600 \mathrm{t}$ of production (Zubiaurre, 2013), and reached $22000 \mathrm{t}$ in

732015 , thus representing almost $50 \%$ of the total European production. Organic

74 aquaculture products are increasingly important on the Swiss market; a growth of $35 \%$ of

75 market volume was observed from 2008 to 2009. A total of 7 organic trout farms produce

76 about $300 \mathrm{t}$ of organic trout in Switzerland (Kilcher et al. 2011). Organic aquaculture

77 production has recently started in Greece (Perdikaris and Paschos 2010; Polymeros et al.

78 2014), and it is also beginning in Turkey (Kayhan \& Olmez 2014) and in Scandinavian

79 countries (Paisley et al. 2010). The only abnormal case in Europe is Ireland, which is the

80 leading country for organic salmon production in Europe, where the production of

81 organic salmon was $69 \%$ of the total salmon production and organic trout was $30 \%$ of the

82 total trout production in 2012 (Zubiaurre, 2013) and successively reached $100 \%$ of

83 production. This extraordinary progress is exclusively due to a change in legislation. In

84 fact, the entire Irish farmed salmon production (13.000 $\mathrm{t}$ in 2015) is obtained according to

85 an organic standard, that is the Annual Aquaculture Survey 2016 issued by the Irish Sea

86 Fisheries Board

(BIM).

87 (http://www.eumofa.eu/documents/20178/84590/Study+report_organic+aquaculture.pdf).

88 The Irish case indicates that the harmonization of rules at a European level is a crucial

89 issue for the future of organic aquaculture. For this reason, it is important to point out the

90 efforts of the European Commission, which amended the previous regulation on organic 
91 production (EC 88/2008) and produced a new regulation in April 2016 (EU 2016/673).

92 This regulation contains more restrictive rules on the introduction of non-organic

93 juveniles into organic farms, both for fish and bivalves, as well as an updated list of feed

94 additives. These rules make the separation between conventional and organic farming

95 clearer in all the productive phases and could improve fish feed quality, considering that

96 it is a central issue for modern organic aquaculture (Ballester-Moltò et al. 2017).

98 Low numbers mean instability and turbulence: an unexpected mathematical side of

99 the question

100 As the total number of organic farms can be considered as a physical system, it could be

101 useful to consider whether this system is stable or not. In terms of system dynamics, it is

102 easy to consider this system as a pendulum that oscillates about the equilibrium position.

103 This equilibrium position is the current number of organic fish farms in Italy (or in

104 Europe or elsewhere). Being composed of a low number of elements (i.e. Italian organic

105 farms), this system is inherently unstable, as a small increase or decrease in the number of

106 farms could result in a great oscillation (Tab. 1), which can easily cause either the end of

107 the system or its transition to a new equilibrium position. This analogy helps to clarify

108 why it is difficult to estimate organic aquaculture productions.

109 In Europe, the number of organic farms was about 75 in 2011 (EU, 2014). Therefore,

110 only a few new farms per year influence the estimated growth to a great extent (Tab. 1).

111 The growth of organic aquaculture has been relevant in relative terms, but not in absolute

112 terms, and this fact has probably created excessive expectations. Even though there are

113 no official statistics on organic aquaculture production at present, if the production 
114 volumes are considered, it is likely that very few new farms have been founded or

115 converted from conventional to organic throughout Europe in the last few years (Fig. 3).

116 For example, in Greece there were 3 organic fish farms until 2013, and in Switzerland

117 there are currently only 7 organic trout farms.

118

119 A snapshot of the Italian aquaculture situation: the effect of intra-sectorial forces on 120 organic aquaculture

121 Organic aquaculture, by definition, is a modern extension of aquaculture, and it is based

122 on an upgrade of the existing conventional aquaculture productive processes. For this

123 reason, a brief description of the current situation of Italian aquaculture is useful to fully

124 understand the status and potentialities of organic aquaculture.

125 Italian aquaculture is structured in the same ways as in other European countries, that is,

126 it is largely based on a few species: namely, three finfish, rainbow trout (Oncorhynchus

127 mykiss Walbaum 1792), European sea bass (Dicentrarchus labrax L.), gilthead sea bream

128 (Sparus aurata L.), and two bivalve species, Mediterranean mussels (Mytilus

129 galloprovincialis L.) and Manila clams (Venerupis philippinarum Adams \& Reeve, 1850)

130 (Bronzi et al. 2012). The production of rainbow trout reached 36000 tons in 2013, while

131 the sea bass and gilthead sea bream volumes were 6300 and 6100 tons, respectively, and

132 bivalve marine farming production reached 88000 tons. The overall value was $€ 393$

133 million in 2013 (MiPAAF 2014). Italy is the main European producer of Manila clams

134 (24600 tons in 2013), while other fish species with promising perspectives are sturgeons

135 for caviar production, grey mullets (Mugil sp.), which are extensively farmed for the

136 production of salted roe, also known as "bottarga", and meagre (Argyrosomus regius 
137 Asso, 1801). Bivalve farming is deeply rooted in Italy, and it is particularly developed

138 along the Adriatic coast, with the Manila clam farms mainly being located in North East

139 Italy. The annual fish consumption in Italy is currently less than $20 \mathrm{~kg}$ per person, and it

140 is the first time in this century that the annual fish consumption has reached such a low

141 value, with a negative trend of $-4 \%$ from 2002 (ISMEA, 2013). Moreover, fish

142 consumption is much lower in Italy than in other European countries, such as Portugal

143 (60 kg), Spain (49 kg) and France (33 kg).

145 The regulatory aspects of organic aquaculture in Italy: the role of politics

146 One of the most important aspects that has influenced the diffusion of organic

147 aquaculture in Italy and throughout the world is the adoption of shared and standardized

148 procedures (Bronzi et al. 2011; Szeremeta et al. 2010). The introduction of standardized

149 procedures has been perceived as crucial from the very beginning of modern Italian

150 aquaculture (Roncarati et al. 2008), and several farmers voluntarily decided to apply

151 internal rules in order to standardize quality, but these practices were only spontaneously

152 adopted by farmers until 1999. Since 2001, an Italian consortium that represents the main

153 stakeholders in the Italian fishery sector for the promotion of fish and seafood

154 consumption (UNIPROM), has organized and promoted research initiatives on organic

155 aquaculture and formulated a preliminary production protocol for organic aquaculture

156 (AAVV 2001). This protocol was based on the FAO Code of Conduct of Responsible

157 Fisheries (FAO 1995) and on Directive (EC) 1804/1999. Later, Directive (EC) 710/2009,

158 which is the regulatory document for organic aquaculture in Europe, was adopted in Italy

159 in July 2010. The Italian Ministry of Agriculture and Forestry supported the adoption of 
160 Directive (EC) 710/2009 and constituted a permanent committee on organic aquaculture 161 (AAVV, 2012). Directive EC 710/2009 introduced fundamental new indications, such as

162 an organic logo and a clear list of ingredients for fish feeds. The principal institution

163 involved in organic aquaculture certification in Italy is ICEA (Ethical and Environmental

164 Certification Institute). Currently, the main food chain that diffuses organic fish is

165 “ALMA VERDE BIO” (www.almaverdebio.it). Clear labeling is a crucial point for the 166 future of organic aquaculture. Since the introduction of organic products onto the market,

167 European consumers have appeared confused about the meaning of the term "organic" 168 and are largely unaware of the certification processes (Aarset et al. 2004). Feucht and 169 Zander (2014) showed that, even in Germany, where there is a deeply-rooted tradition of 170 organic food consumption, there was still a necessity to improve organic fish labeling and 171 communication with consumers.

173 Organic aquaculture productions in Italy

174 The total production of Italian organic aquaculture was of $2347 \mathrm{t}$ in 2015 , which 175 represents $1.1 \%$ of the total Italian aquaculture production. In the past, organic 176 aquaculture in Italy was at a constant level, that is at $1.5-2 \%$ of the total aquaculture 177 production. Blue mussel was the main species organically farmed in 2015, with 2000 178 tons of production, while gilthead sea bream was the first fish farmed species, with a 179 production of 153 t; rainbow trout is the second organically farmed species, with a 180 production $\quad$ of $\quad 90 \quad t$ 181 (http://www.eumofa.eu/documents/20178/84590/Study+report_organic+aquaculture.pdf). 182 The internal Italian demand for organic aquaculture products was already noticeable 
183 when organic fish production began in Italy (Defrancesco, 2003), and in the last few

184 years, a willingness to pay a premium price for organically farmed fish has been noticed

185 (Maurarcher et al. 2013). Organic productions are well known by Italian consumers, and

186 Italy is in fact ranked $3^{\text {rd }}$ in the world, after Australia and Argentina, for the use of

187 certified soil in organic agriculture production (AA VV 2012). Overall, the number of

188 agriculture organic certified farms in Italy increased from 48,269 in 2011 to 49,709 in

1892012 (Ribeiro et al. 2010), and now represents 25\% of the total European organic

190 production. Italian organic agricultural and livestock products are mainly exported to

191 Northern Europe. Organic aquaculture production in Italy started in $2000-2001$, with a

192 few trout farms that were certified by independent certification bodies (AAVV, 2001). In

193 the subsequent years, some organic gilthead sea bream and European sea bass farms were

194 founded, following the application of a specific regulation for organic fish farming, that

195 is, Directive (EC) 710/2009 (Defrancesco 2003). Italian organic aquaculture production

196 was originally based on just a few aquaculture farms, but the number increased to 17

197 farms in 2013, thus showing a comparable situation with most other European countries.

198 Recent data on organic fish farms (SINAB, 2014; SINAB 2015) indicated an unexpected

199 increase to 41 farms in 2014 with a successive stationary phase until 2017 (SINAB,

200 2018), thus showing an increase of more than $140 \%$. The small number of farms and this

201 sudden increase in 2014 make it difficult to clearly interpret this trend. However, this

202 number represents $5.1 \%$ of the total number of Italian aquaculture farms, and it is

203 noticeably higher than the European percentage of 1.3\% (with the exception of Ireland).

204 Should this trend be confirmed, it could indicate a quite positive change in perspective 205 that is in contrast with the rest of Europe (EU, 2014). Italian organic farms are mainly 
206 located along the Adriatic coast (Fig. 2); the Veneto region (NE Italy) has the greatest

207 number of organic aquaculture farms and is also the leading conventional aquaculture

208 region. The most common organically farmed fish species is gilthead sea bream

209 (Castellini et al. 2014).

210 These data show that Italian organic aquaculture has an inner relationship with

211 conventional aquaculture. In fact, the most popular organic species are the most

212 frequently farmed conventional species, with the only difference concerning the produced

213 amount, in that organic gilthead sea bream production is higher than rainbow trout

214 production, while rainbow trout production is higher than gilthead sea bream in

215 conventional aquaculture . This fact can be explained considering that Italian rainbow

216 trout farming is currently managed with traditional techniques and with traditional

217 infrastructures, while marine aquaculture is a more recent activity and is consequently

218 more open to technological improvements.

219 It seems that the positive growth perspectives expected at the international level,

220 pertaining to organic aquaculture productions, such as that indicated by FAO, which

221 estimated a growth of $40-60 \%$ until 2012 (Prein et al. 2012) and an expected growth of

$22220 \%$ per year between 2010 and 2020 (Nizza, 2012), do not show similar trends for Italy.

223 Moreover, Italy is one of the countries with the highest numbers of processing plants for

224 organic fish

225 (http://epp.eurostat.ec.europa.eu/portal/page/portal/organic farming/data/database), thus

226 indicating a good internal demand for organic aquaculture products and a strong modern

227 aquaculture specialization process (Guillotreau 2004). 
228 Until 2013, organic aquaculture in Italy remained stationary at a low level, but this

229 situation was comparable with the situations of other western countries (IFOAM 2010b),

230 with the exception of Ireland (Fig. 3) (Budak et al. 2006; Defrancesco, 2003; Mente et al.

231 2011). Subsequently, from 2014 to 2017, the number of organic fish farms had

232 unexpectedly more than doubled, thus representing a radically different situation from

233 other European countries. The main explanation for this difference may be geographic

234 (the local conditions positively affected the transformation of conventional farms into

235 organic ones). In fact, if the distribution of organic farms in 2013 is compared with that

236 of 2014-2018 (SINAB 2014; SINAB 2015; SINAB 2018), it is clear that the increase in

237 the number of organic farms is principally due to the two regions, Veneto and Emilia

238 Romagna, in which the number of organic farms doubled in 2014. It is clear that there are

239 more opportunities for conversion from conventional to organic productions in areas in

240 which aquaculture has traditionally developed.

241 Although some recent studies in Greece and in Italy have shown that organic feeds

242 sustain a good performance of sea bass and sea bream (Di Marco et al. 2017; Mente et al.

243 2012), the diffusion of organic farming practices in small-size fish farms in Italy is

244 principally hampered by the high costs of certification and fish feeds (IFOAM, 2010b)

245 and by the excessive bureaucracy (SINAB, 2015). For instance, a cost-benefit assessment

246 in a European sea bass farm has recently shown that the costs of certification and fish

247 feeds are the main obstacles to the conversion from conventional to organic production

248 (Zacchino et al. 2014). The adoption of Directive EC 710/2009 has been a fundamental

249 achievement for Italian organic aquaculture and has promoted its diffusion, but there are

250 still some problematic aspects for the farmers: the sanitary treatments based on natural or 
251 vegetal compounds and probiotics, the mandatory utilization of only local fish strains; the

252 mandatory spatial separation between conventional and organic cultures during all the

253 productive phases and the restricted use of water oxygenation (Trocino et al. 2012; Tulli

254 et al. 2012).

255 From the commercial point of view, there are also some critical aspects that should be

256 addressed: the difficulty of introducing organic aquaculture products into the large-scale

257 retail trade, the higher prices, compared to conventional food products, and the

258 application of appropriate marketing strategies, following the example of Denmark (see

259 the ORAQUA project (2007-2010): http://www.icrofs.org/pdf/darcofIII/oraqua.pdf).

260 A positive aspect recently emerged by the project BIOBREED

261 (http://www.biobreed.it/BioBreed/HOME.html) is the positive consumer's perception of

262 organic aquaculture products as reaction to a general negative sentiment of conventional

263 aquaculture products. Italian consumers believe that pharmaceutical treatments are

264 strongly reduced in organic aquaculture (Pulcini \& Capoccioni 2018). Italian consumers

265 will need to be informed and a clear labeling, (according the EU and international

266 standards) is imperative in order to control the abuse of such terms as "organic" and

267 "biological" in aquaculture products.

268

269 Conclusions

270 Italian organic aquaculture is 20 years old, but it is often considered to still be in its

271 infancy, and this review indicates that it will probably remain in this situation in the

272 future. It can be stated that this is a physiological state, thus Italian organic aquaculture

273 can be considered a "proportioned dwarf" in the aquaculture sector. 
274 Blue mussel, gilthead sea bream and rainbow trout are the most important organically

275 farmed species in Italy, and most of the organic fish farms are located along the Adriatic

276 coast and in North East Italy.

277 The high costs of certification and fish feeds, the bureaucracy, the higher prices and the

278 lack of appropriate marketing strategies are the main practical obstacles to Italian organic

279 aquaculture.

280 It appears that the Italian rules for organic aquaculture production are probably too

281 restrictive to promote organic farming, and this is just a part of the problem that affects

282 aquaculture production in general. For this reason, the main policy implication is that a

283 simplification should be introduced in order to sustain the internal production of organic

284 aquaculture and the entire sector.

285 The show of optimism repeatedly reported in the previsions about organic aquaculture in

286 Italy and in other developed countries should be tempered. The data of the last 20 years

287 on organic aquaculture clearly show that its production is just a small percentage of the 288 total aquaculture production.

289 In general terms, it is clear that the relationship between conventional and organic 290 aquaculture can easily be explained in a context of evolutionary relationships. In fact, the 291 emergence and diffusion of organic aquaculture show powerful analogies with the 292 emergence of a new species, in a process of intra-specific separation, which is well

293 known in biology. A new species (in this case organic aquaculture) originates from the 294 former one (conventional aquaculture), in a gradual process that is driven by internal 295 (aquaculture productions) and external (geographical and legislative) forces. 
296 The vision and the perspective of the future of organic aquaculture would be greatly

297 improved if the scientific community were able to include the organic aquaculture

298 evolution in a general theoretical context, beyond the traditional boundaries of technical

299 considerations that dominate modern scientific literature.

300

301 Acknowledgments

302 I am grateful to Prof. Martin P. Schreibman from the Department of Biology at Brooklyn

303 College (USA) for editing a previous version of this article and for his useful comments. I

304 would also like to thank Mrs. M. Jones for professional English Language editing and

305 correction. This research did not receive any specific grant from funding agencies in the

306 public, commercial or not-for-profit sectors.

307

308

309 References

310 AAVV (2001) Verso l'acquacoltura biologica Un programma UNIPROM al servizio dei

311 consumatori e dei produttori (in Italian). Consorzio Uniprom, Roma, p.198

312 AAVV (2011) Indagine sull'acquacoltura biologica (in Italian). API - COISPA, Bari, p.

$313 \quad 63$

314 Aarset B, Beckmann S, Bigne E, Beveridge M, Bjorndal T, Bunting J, McDonagh P,

315 Mariojouls C, Muir J, Prothero A, Reisch L, Smith A, Tveteras R, Young J (2004)

316 The European consumers' understanding and perceptions of the "organic" food

317 regime. The case of aquaculture. British Food Journal. 106, 93 - 105 
318 Ballester-Moltó M, Follana-Berná G, Sanchez-Jerez P, Aguado-Giménez F (2017) Total

319 nitrogen, carbon and phosphorus digestibility in gilthead seabream (Sparus aurata)

320 and European seabass (Dicentrarchus labrax) fed with conventional and organic

321 commercial feeds: implications for particulate waste production. Aquaculture

$322 \quad$ Research 48, $3450-3463$.

323 Bronzi P, Rambaldi E, Cardillo A, Dell'Aquila M, Di Dato P, Cataudella S (2012)

324 The state of Italian aquaculture. In: Cataudella S and Spagnolo M (eds). The state

325 of Italian marine fisheries and aquaculture Italian Ministry of Agriculture, Food and

326 Forestry Policies, pp $239-269$ Rome. Available at

327 http://www.politicheagricole.it/flex/cm/pages/ServeBLOB.php/L/IT/IDPagina/6412

328 Budak F, Budak DB, Kacira OO,Yavuz MC (2006) Consumer willingness to pay for 329 organic sea bass in Turkey. Israeli Journal of Aquaculture-Bamidgeh 58 (2), 116 $330 \quad 123$

331 Castellini A, De Boni A, Mauracher C, Gaviglio A, Ragazzoni A, Roma R (2014)

332 The organic aquaculture sector in Italy: a Delphi evaluation of the market

333 potentialities. In: Proceedings of the 4th ISOFAR Scientific Conference 'Building

334 Organic Bridges', at the Organic World Congress 2014(Rahamann G and Aksoy

335 (Eds.) pp $769-772$. Istanbul Turkey

336 Cottee SY, Petersen AP (2009) Animal Welfare and Organic Aquaculture in Open

337 Systems. Journal of Agricultural and Environmental Ethics 22, 437-461

338 EU (2014) Regulation of the European Parliament and of the Council on organic 339 production and labelling of organic products, amending Regulation (EU) No

$340 \mathrm{XXX} / \mathrm{XXX}$ of the European Parliament and of the Council and repealing Council 
342 http://ec.europa.eu/agriculture/organic/documents/eu-policy/policy-

343 development/impact-assessment/impact-assessment-part2_en.pdf (accessed March 15, $344 \quad 2016)$

345 Defrancesco E (2003) The Beginning of Organic Fish Farming in Italy. TeSAF 346 Department, University of $\quad$ Padova. 347 athttp://www.feem.it/Feem/Pub/Publications/WPapers/default.html

348 Di Marco P, Petochi T, Marino G, Priori A, Finoia M G, Tomassetti P, Parisi G, Porrello

349 S, Giorgi G, Lupi P, Bonelli A, Parisi G, Poli B M (2017) Insights into organic

350 farming of European sea bass Dicentrarchus labrax and gilthead sea bream Sparus

351 aurata through the assessment of environmental impact, growth performance, fish 352 welfare and product quality. Aquaculture 471, 92-105.

353 Feucht Y, Zander K (2014) Consumers' knowledge and information needs on organic

354 aquaculture. In: Proceedings of the 4th ISOFAR Scientific Conference Building 355 Organic Bridges', at the Organic World Congress 2014 (Rahamann G and Aksoy $356 \quad$ (Eds.) pp $13-15$. Istanbul Turkey

357 Guillotreau P (2004) How does the European seafood industry stand after the revolution 358 of salmon farming: An economic analysis of fish prices. Marine Policy 28, 227-233

359 IFOAM (2010a) (International Federation of Organic Agriculture Movements) Organic 360 Aquaculture. Available at URL: http://ifoam.org/about_ifoam/around_world/ 361 eu_group-new/positions/publications/aquaculture/

362 IFOAMEU_IAMB_organic_aquaculture_dossier.pdf 
363 IFOAM (2010b) Organic Aquaculture EU Regulations (EC) 834/2007, (EC) 889/2008,

364 (EC) 710/2009. Background, Assessment, Interpretation. pp 36

365 ISMEA (2013) CHECK UP 2013 - Il settore ittico in Italia (in Italian) p 129 available

366 online at:

367 http://www.ismea.it/flex/cm/pages/ServeAttachment.php/L/IT/D/5\%252Ff\%252F2\%2

368 52FD.cc060abd05429fb5996b/P/BLOB\%3AID\%3D8845

369 Kayhan MH, Olmez M (2014) Aquaculture and Organic Aquaculture in Turkey. Journal

$370 \quad$ of Aquatic. Research Development, 5, 259-254

371 Kilcher L, Willer H, Huber B, Frieden C, Schmutz R, Schmid O (2011) The Organic

372 Market in Europe: 3rd edition March 2011, SIPPO, Zürich and FiBL, Frick 147 pp

373 (available at https://www.fibl-shop.org/english/shop/index.php)

374 Kormas K A, Meziti A, Mente E, Frentzos A (2014) Dietary differences are reflected on

375 the gut prokaryotic community structure of wild and commercially reared sea bream

376 (Sparus aurata). Microbiologyopen, 3 (5), 718-728.

377 Lima JSG, Rivera EC, Focken C (2012) Emergy evaluation of organic and conventional

378 marine shrimp farms in Guaraíra Lagoon, Brazil. Journal of Cleaner Production 35,

$379 \quad 194-202$

380 Lund I, Dalsgaard J, Tolderlund T, Rasmussen H, Holm J, Jokumsen A (2011)

381 Replacement of fish meal with a matrix of organic plant proteins in organic trout

382 (Oncorhynchus mykiss) feed, and the effects on nutrient utilization and fish

383 performance. Aquaculture 321, 259-266

384 Mansfield B (2007) Organic view of the nature: the debate over organic certification for

385 aquatic animals. Sociologia Ruralis 44, (2): 216-232 
386 Mauracher C, Tempesta T, Vecchiato D (2013) Consumer preferences regarding the

387 introduction of new organic products. The case of the Mediterranean sea bass

388 (Dicentrarchus labrax) in Italy. Appetite 63, 84-91

389 Menghe HL, Robinson EH, Mischke, C C, Torrans ELV, Bosworth B G (2006) Effects

390 of organic fertilization and organic diets on production of channel catfish in earthen

391 ponds. North American Journal of Aquaculture 68 (1), 53 -62

392 Mente E, Karalazos V, Karapanagiotidis LD, Pita C (2011) Nutrition in organic

393 aquaculture: an inquiry and a discourse. Aquaculture Nutrition 17, 798-817

394 Mente E, Stratakos A, Boziaris I S, Kormas K A, Karalazos V, Karapanagiotidis I T,

395 Catsiki V, Leondiadis L. (2012) The effect of organic and conventional production

396 methods on sea bream growth, health and body composition: a field experiment.

$397 \quad$ Scientia Marina 76 (3), 549-560.

398 Michaud J (2011) New standard launched in Australia. Available at

399 URL:http://www.organicstandard.com/read-it-online/175-2011-april/2514-new-

$400 \quad \underline{\text { standard-launched-in-australia }}$

401 MiPAAF (2014) Piano Strategico per l' Acquacoltura in Italia (2014-2020). pp.282.

402 Nizza A (2012) What Future for Organic Aquaculture? Journal of Aquaculture Research

403 Development 3:e103 doi:10.4172/2155-9546.1000e103

404 Paisley LG, Ariel E, Lyngstad T, Jonsson G, Vennerstrom P, Hellstrom A, Østergaard

405 P (2010) An overview of aquaculture in the Nordic countries, Journal of World

406 Aquaculture Society 41,(1):1-17

407 Perdikaris C, Paschos I (2010) Organic aquaculture in Greece: a brief review. Reviews 408 in Aquaculture 2, 102-105 
409 Polymeros K, Kaimakoudi E, Mitsoura A, Nikouli, E, Mente E (2014) The determinants

410 of consumption for organic aquaculture products-evidence from Greece. Aquaculture

411 Economics \& Management, 18, 45-59

412 Prein M, Bergleiter S, Ballauf M, Brister D, Halwart M, Hongrat K, Kahle J, Lasner

413 T, Lem A, Lev O, Morrison C, Shehadeh Z, Stamer A,Wainberg AA, (2012)

414 Organic aquaculture: the future of expanding niche markets. In:Farming the Waters

415 for People and Food. Proceedings of the Global Conference on Aquaculture 2010

416 (Subashinghe, RP, Arthur JR, Bartley DM, De Silva SS, Halwart M, Hishamunda

417 N, Mohan CV and P Sorgeloos Eds.). pp 549-567. Bangkok

418 Pulcini D, Capoccioni F (2018). Il consumo di pesce allevato e biologico in Italia (In

419 Italian). Edizioni BetMultimedia pp 66. Available on line at

420 http://www.biobreed.it/BioBreed/HOME_files/Il\%20consumo\%20di\%20pesce\%20all

421 evato\%20e\%20Biologico\%20in\%20italia.pdf

422 Ribeiro L, Soares F, Cunha ME, Pousão-Ferreira P (2010) Organic Aquaculture: a

423 strategy for valorisation of semi-intensive aquaculture?, In International Workshop on

424 Sustainable Extensive and Semi-intensive Aquaculture Production in Southern

425 Europe. (Stiftung Ökologie \& Landbau, Eds.) Tavira, Portugal. Available at

426 http://www.seacase.org/PDF/WP7

427 Roncarati A, Melotti P, Felici A, Dees A, Pignata S (2008) Comparison of qualitative 428 traits of European sea bass (Dicentrarchus labrax), of different provenance, 429 commercialized by an Italian supermarket company. In Seafood from catch and 430 aquaculture for a sustainable supply (Poli MB and G Parisi Eds.). Book of abstracts, 431 p 20;16 - 20 September 2008, Florence, Italy 
432 SINAB (2014). BIO in cifre $2014 \quad 81$ pp Available at

433 http://www.sinab.it/sites/default/files/share/OK!!.pdf (In Italian)

434 SINAB (2015) BIO in cifre $2015 \quad 94$ pp Available at

$435 \quad$ http://www.sinab.it/sites/default/files/share/OK!!.pdf (In Italian)

436 SINAB (2018) BIO in cifre - Anticipazioni 2018 Available online at

437 http://www.openfields.it/sito/wp-content/uploads/2018/09/Bio-in-cifre-2018-_-

$438 \quad$ Anticipazioni.pdf (In Italian) pp 28

439 Subasinghe R, Soto D, Jia J (2009) Global aquaculture and its role in sustainable

440 development. Reviews in Aquaculture 1, 2-9

441 Szeremeta A, Winkler L, Blake F Lembo G (2010) Organic Aquaculture EU

442 Regulations (EC) 834/2007, (EC) 889/2008, (EC) 710/2009. Background, assessment, 443 interpretation. IFOAM EU Group, pp 36.

444 Trocino A, Xiccato G, Majolini D, Tazzoli M, Bertotto D, Pascoli F, Palazzi R (2012)

445 Assessing the quality of organic and conventionally-farmed European sea bass

446 (Dicentrarchus labrax). Food Chemistry 131, 427-433

447 Tulli F, Chini Zittelli G, Giorgi G, Poli B M, Tibaldi E, Tredici MR (2012) Effect of 448 the inclusion of dried Tetraselmis suecica on growth, feed utilization, and fillet 449 composition of European sea bass juveniles fed organic diets. Journal of Aquatic $450 \quad$ Food Product Technology 21, (3): 188-197

451 Turchini G, Torstensen BE, Ng W (2009) Fish oil replacement in finfish nutrition. $452 \quad$ Reviews in Aquaculture 1, 10-57

453 Tusche K, Wuertz S, Susenbeth A, Schulz C (2011) Feeding fish according to organic 454 aquaculture guidelines EC 710/2009: Influence of potato protein concentrates 
455 containing various glycoalkaloid levels on health status and growth performance of 456 rainbow trout (Oncorhynchus mykiss). Aquaculture 319, 122-131

457 Xie B, Qin J, Yang H, Wang X, Wang Y, Li T (2013) Organic aquaculture in China:

458 A review from a global perspective. Aquaculture 414, 243-253

459 Zacchino V, De Boni A, Gorgoni P, Novelli A, Centoducati G, Roma R (2014) Technical

460 and economic feasibility of seabass fry production according to organic techniques.

461 In: Proceedings of the 4th ISOFAR Scientific Conference 'Building Organic

462 Bridges', at the Organic World Congress 2014 (Rahamann G and Aksoy (Eds.) pp

$463749-754$. Istanbul Turkey

464 Zubiaurre C (2013) The current status and future perspectives of European Organic $465 \quad$ Aquaculture. Aquaculture Europe 38: 14-21 
Fig. 1

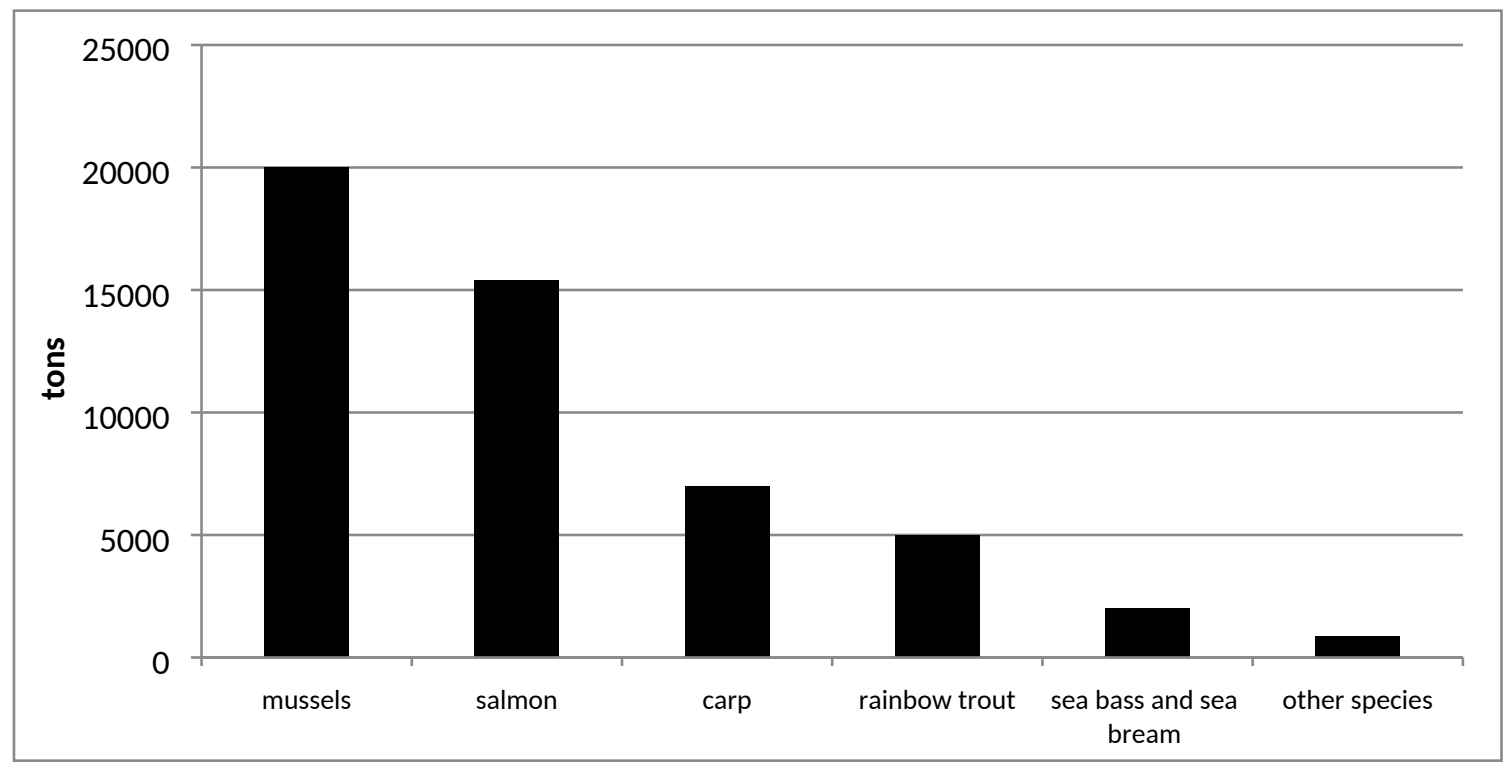


Fig 2.

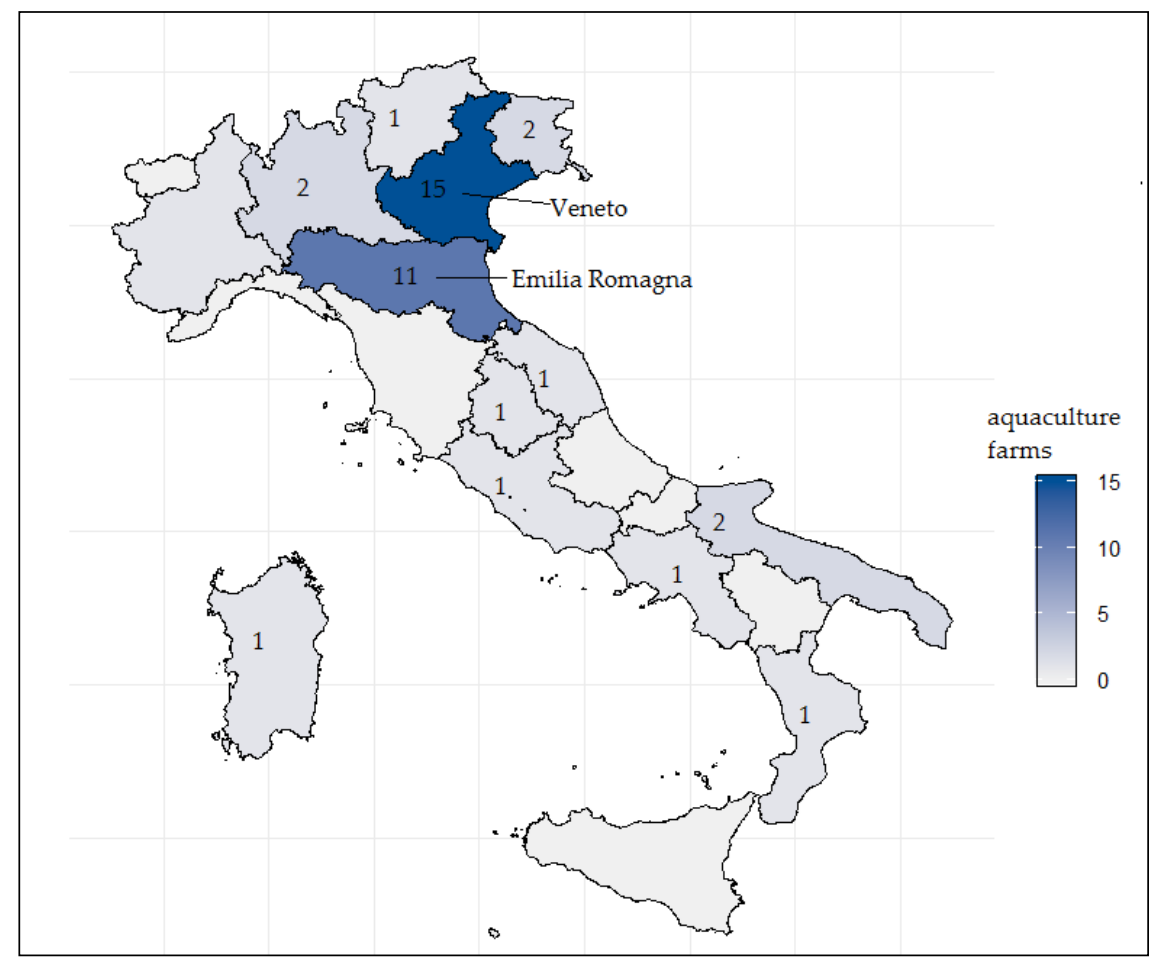


Fig. 3

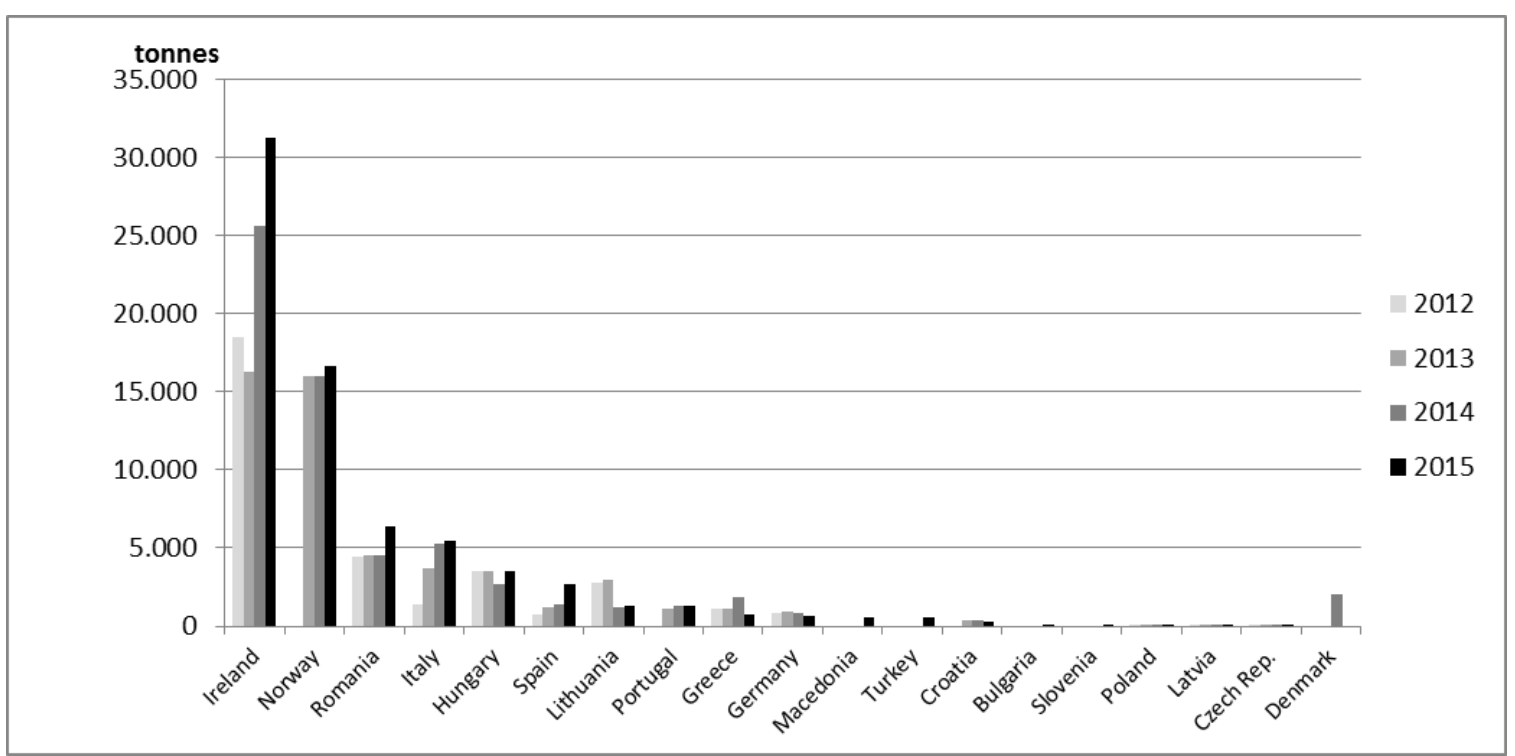


2 Tab. 1 Annual relative increment (\%) of organic aquaculture production in main

3 European countries from 2012 to 2015

4

5

\begin{tabular}{lccc}
\hline Country & $2012-2013$ & $2013-2014$ & $2014-2015$ \\
\hline Ireland & $-12 \%$ & $57 \%$ & $22 \%$ \\
Norway & & $0 \%$ & $4 \%$ \\
Romania & $3 \%$ & $-1 \%$ & $41 \%$ \\
Italy & $166 \%$ & $44 \%$ & $4 \%$ \\
Hungary & $0 \%$ & $-23 \%$ & $31 \%$ \\
Spain & $53 \%$ & $15 \%$ & $99 \%$ \\
Lithuania & $10 \%$ & $-61 \%$ & $10 \%$ \\
Portugal & & $18 \%$ & $0 \%$ \\
Greece & $3 \%$ & $66 \%$ & $-61 \%$ \\
Germany & $10 \%$ & $-16 \%$ & $-22 \%$ \\
Croatia & & $-16 \%$ & $-12 \%$ \\
\hline
\end{tabular}

6 
$2 \quad$ Figure captions

3

4 Fig. 1 Number of organic aquaculture farms in Europe in 2009, divided by species 5 (IFOAM, 2010)

6

7 Fig 2. Number of organic aquaculture farms in Italy in 2017, divided by region (SINAB, 8 2018)

9

10 Fig 3. Number of organic aquaculture farms in Europe from 2012 to 2015.

11

12

13

14

15 
An overview of organic aquaculture in Italy

2 Benedetto Sicuro

3 Department of Veterinary Sciences, L. go Braccini, 2, 10095 Grugliasco, (TO), Italy

4 E-mail: benedetto.sicuro@unito.it, tel +39 011 6709260, fax + 390116709240

5

6 Running title: An over. Organ. Aquac. Italy 
Dear Editor,

I have tried to reply to the reviewer 2 requests at my best

I carefully searched for recent articles about Italian organic aquaculture. I included updated references in the manuscript.

I sent again the manuscript for a professional English revision to a lecture, that I already acknowledged in the article, here her last email

"Dear Benedetto,

I am sending you the revised version. I have made a few suggestions that are perhaps not necessary, but might be useful to show the editor/referee you have paid attention to his/her comments. This person is probably not a mother-tongue (as deduced from his/her strange comments about grammar!). However, there were a few grammar mistakes in the version (e.g. where you forgot to remove a word). If you need a $\mathrm{CV}$ to send to him/her, I can send it to you. Let me know how this goes. "

I hope that the you and the reviewer2 will consider my corrections as definitive, but I am still available to re-correct my manuscript, if necessary.

Best regards, Benedetto Sicuro 